\section{KEPUASAN KERJA SEBAGAI MEDIATOR ANTARA IKLIM ORGANISASI DAN MOTIVASI TERHADAP KINERJA GURU DI KABUPATEN TEMBILAHAN}

Rafiuddin Afkari

rafiuddin@uthm.edu.my

\author{
Hazriyanto
}

hazriyanto@gmail.com

Siti Marfuah

puah1976@gmail.com

\section{A. Pendahuluan}

Memasuki era baru perkembangan dunia pendidikan di Indonesia menjadi makin marak. hal tersebut bukan disebabkan oleh kehebatan mutu pendidikan nasional tetapi lebih banyak disebabkan karena kesadaran akan bahaya keterbelakangan pendidikan di Indonesia.

Penyelenggaraan pendidikan di Indonesia merupakan suatu sistem pendidikan nasional yang diatur secara sistematis. Pendidikan nasional berfungsi mengembangkan kemampuan dan membentuk watak serta peradaban bangsa yang bermartabat dalam rangka mencerdaskan kehidupan bangsa, bertujuan untuk berkembangnya potensi peserta didik agar menjadi manusia yang beriman dan bertakwa kepada Tuhan Yang Maha Esa, berakhlak mulia, sehat, berilmu, cakap, kreatif, mandiri, dan menjadi warga negara yang demokratis serta bertanggung jawab (UU No. 20 Tahun 2003).

Guru merupakan unsur yang sangat mempengaruhi tercapainya tujuan pendidikan selain unsur murid dan fasilitas lainnya. Keberhasilan penyelenggaraan pendidikan sangat ditentukan kesiapan guru dalam mempersiapkan peserta didiknya melalui kegiatan belajar mengajar. Guru merupakan faktor yang paling dominan dan paling penting dalam pendidikan formal yang pada umumnya bagi siswa guru sering dijadikan tokoh teladan bahkan menjadi tokoh identifikasi diri.
Fenomena dilapangan yang terjadi tidak dapat dipungkiri yang mencerminkan keadaan guru yang tidak lagi sesuai dengan harapan seperti rendahnya motivasi guru, kompetensi guru yang masih jauh dari ideal dan disiplin guru dalam mengajar yang sangat rendah. Kenyataan ini begitu memprihatinkan dan mengundang berbagai pertanyaan tentang konsistensi guru terhadap profesinya. Guru dituntut memiliki kinerja yang mampu memberikan dan merealisasikan harapan dan keinginan semua pihak terutama masyarakat umum yang telah mempercayai sekolah dan guru dalam membina anak didik.

Kepuasan kerja juga merupakan salah satu faktor penting yang harus diperhatikan, untuk mendapatkan hasil kerja yang optimal. Untuk itu, faktor-faktor yang mempengaruhi kinerja guru yang berdampak kepada kepuasan kerja guru dipandang perlu untuk dipelajari, ditelaah dan dikaji secara mendalam agar dapat memberikan gambaran yang jelas faktor yang lebih berperan yang mempengaruhi kinerja guru.

\section{B. Kerangka Teoritis dan Perumusan Hipotesis}

1. Model Penelitian Terdahulu

Rismawati (2008) melakukan penelitian mengenai Motivasi Kerja, Budaya Organisasi dan Kinerja. Model penelitiannya dapat dilihat dari Gambar 2.12.

Gambar 2.12. Kerangka Konsep Penelitian

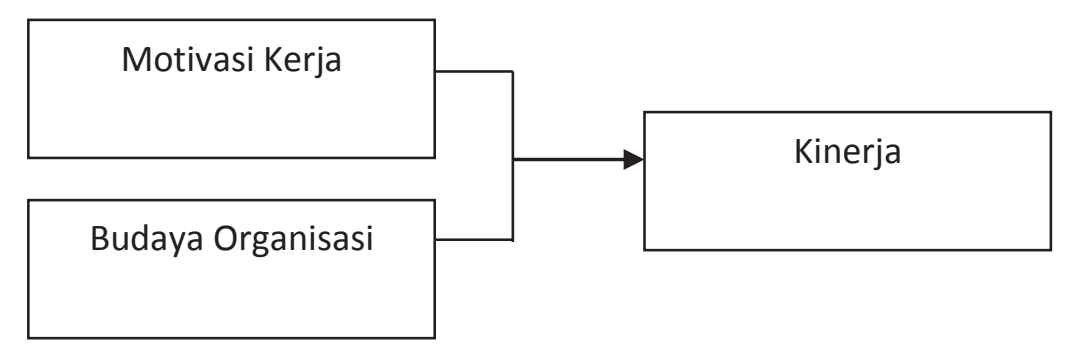

\section{Kerangka Teoritis}

Kerangka konsep penelitian pada dasarnya adalah kerangka hubungan antara konsep-konsep yang ingin diamati atau di ukur melalui penelitian yang akan dilakukan (Notoatmodjo, 2003). 
Sementara Teori menurut Emory - Cooper , merupakan suatu kumpulan konsep, defenisi, proposisi dan variable yang berkaitan satu sama lain secara sistematis dan telah digeneralisasikan sehingga dapat menjelaskan memprediksi suatu fenomena (fakta-fakta) tertentu.

\section{Performance (Kinerja)}

Kinerja karyawan dapat diartikan sebagai prestasi kerja atau hasil kerja (output) baik kualitas maupun kuantitas yang dicapai karyawan per periode dalam melaksanakan tugasnya sesuai dengan tanggungjawab yang diberikan kepadanya. Kinerja merupakan hasil kerja yang dapat dicapai oleh seseorang atau sekelompok orang dalam suatu organisasi, sesuai dengan wewenang dan tanggungjawab masing-masing dalam rangka upaya mencapai tujuan organisasi bersangkutan secara legal, tidak melanggar hukum dan sesuai dengan moral dan etika (Prawirosentono, 1999).

Kinerja menurut Mulyadi (2007) adalah keberhasilan personil, tim, atau unit organisasi dalam mewujudkan sasaran stratejik yang telah ditetapkan sebelumnya dengan perilaku yang diharapkan. Sedangkan kinerja menurut Veithzal Rivai (2005:14) kinerja merupakan hasil atau tingkat keberhasilan seseorang secara keseluruhan selama periode tertentu didalam melaksanakan tugas dibandingkan dengan berbagai kemungkinan, seperti standar hasil kerja, target/ sasaran atau kriteria yang telah disepakati bersama.

Kinerja menurut Mathis dan Jackson yang dikutip oleh Akhmad Subekhi dan Mohammad Jauhar (2012) menyatakan bahwa kinerja pada dasarnya adalah apa yang dilakukan atau tidak dilakukan oleh karyawan. Kinerja karyawan yang umum untuk kebanyakan pekerjaan meliputi elemen sebagai berikut:

a. Kuantitas dari hasil

b. Kualitas dari hasil

c. Kecepatan waktu dari hasil

d. Kehadiran

e. Kemampuan bekerjasama

Menurut Mangkunegara yang dikutip oleh Wahyuningrum (2008) kinerja adalah hasil kerja secara kualitas dan kuantitas yang dicapai oleh seorang karyawan dalam melaksanakan tugasnya sesuai dengan tanggung jawab yang diberikannya.

Dengan demikian dapat disimpulkan bahwa kinerja pada dasarnya merupakan suatu cara atau perbuatan seseorang dalam melaksanakan pekerjaan untuk mencapai hasil tertentu. Kinerja ditentukan oleh kemampuan, keinginan dan lingkungan. Oleh karena itu agar mempunyai kinerja yang baik, seseorang harus mempunyai keinginan yang tinggi untuk mengerjakan dan mengetahui pekerjaannya serta dapat ditingkatkan apabila ada kesesuaian antara pekerjaan dan kemampuan.

\section{Iklim Organisasi}

Menurut Tagiuri dan Litwin dalam Wirawan (2007) yang dikutip oleh Woro (2014) Iklim organisasi merupakan kualitas lingkungan internal organisasi yang secara relatif terus berlangsung, dialami oleh anggota organisasi, mempengaruhi perilaku mereka dan dapat dilukiskan dalam pengertian satu set karakteristik atau sifat organisasi. Stringer (2002) dalam Natassia menefinisikan iklim organisasi sebagai "...collection and pattern of enviromental determinant of aroused motivation." Iklim organisasi sebagai koleksi dan pola lingkungan yang menentukan munculnya motivasi. Dari definisi tersebut dapat disimpulkan definisi iklim organisasi adalah, persepsi anggota organisai baik individu maupun kelompok dan pihak lain yang berhubungan dengan organisasi (misalnya: suplier, nasabah, konsultan, dan lain-lain) secara rutin tentang lingkungan internal organisasi yang akan mempengaruhi sikap dan perilaku anggota organisasi, serta menentukan kinerja organisasi.

\section{Motivasi Kerja}

Supardi dan Anwar (2004) menyatakan bahwa: "motivasi adalah keadaan dalam pribadi seseorang yang mendorong keinginan individu untuk melakukan kegiatan-kegiatan tertentu guna mencapai tujuan".

Menurut Heidjerachman dan Husnan (2002) bahwa: "motivasi merupakan proses untuk mencoba mempengaruhi seseorang agar melakukan sesuatu yang kita inginkan”.

Berdasarkan uraian pendapat diatas dapat disimpulkan bahwa motivasi merupakan suatu dorongan yang menggerakkan seseorang untuk melakukan aktifitas. Seseorang tergerak untuk melakukan sesuatu karena berhubungan dengan kebutuhannya. Motivasi mengarahkan perilaku untuk melaksanakan tugas pekerjaan dengan baik 
guna mencapai tujuan yang telah ditetapkan.

\section{Kepuasan Kerja}

Kotler (2003: 61) mendefinisikan kepuasan sebagai perasaan senang atau kecewa seseorang yang dialami setelah membandingkan antara persepsi kinerja atau hasil suatu produk dengan harapan-harapannya.

Kepuasan kerja adalah bagaimana perasaan karyawan terhadap pekerjaannnya Wexley dan Yukl dalam Hilda.,dkk (2004).

Berdasarkan uraian pendapat diatas dapat disimpulkan bahwa kepuasan sebagai tingkah laku dan perasaan senang seseorang yang dialami setelah membandingkan antara persepsi kinerja dengan harapan-harapannya dan perasaan pegawai terhadap pekerjaannnya.

\section{Model Konseptual}

1. Model Penelitian dan Perumusan Hipotesis

Berdasarkan uraian diatas dan kajian literatur yang telah dibahas sebelumnya, berikut model penelitian dalam penelitian ini yang menunjukkan hubungan antar variabel yang akan diteliti. Inti dari penelitian ini adalah untuk memotret keterkaitan variabel kepuasan kerja sebagai mediator pengaruh antara motivasi dan iklim organisasi terhadap kinerja Guru di Tembilahan.

Gambar 2.5

Model Analisis Keterkaitan Motivasi, Iklim Organisasi, Kepuasan Kerja dan Kinerja

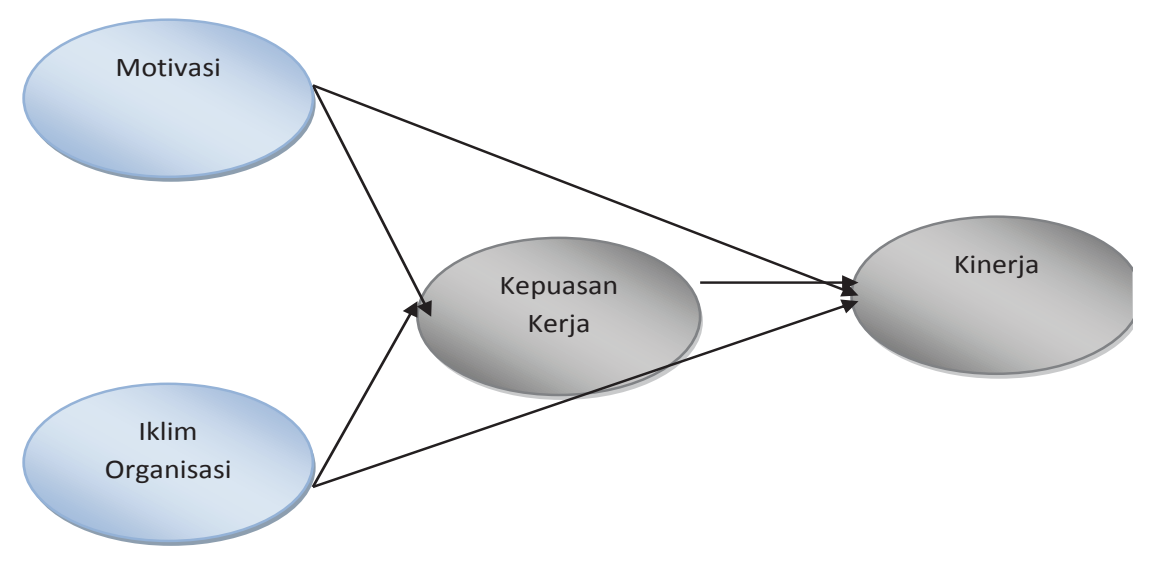

Gambar 2.6

Kaitan Antar Variabel dengan Model Struktur Persamaan (SEM)

Kepuasan Kerja Sebagai Mediator Antara Iklim Organisasi dan Motivasi Kerja Terhadap Kinerja Guru Di Tembilahan

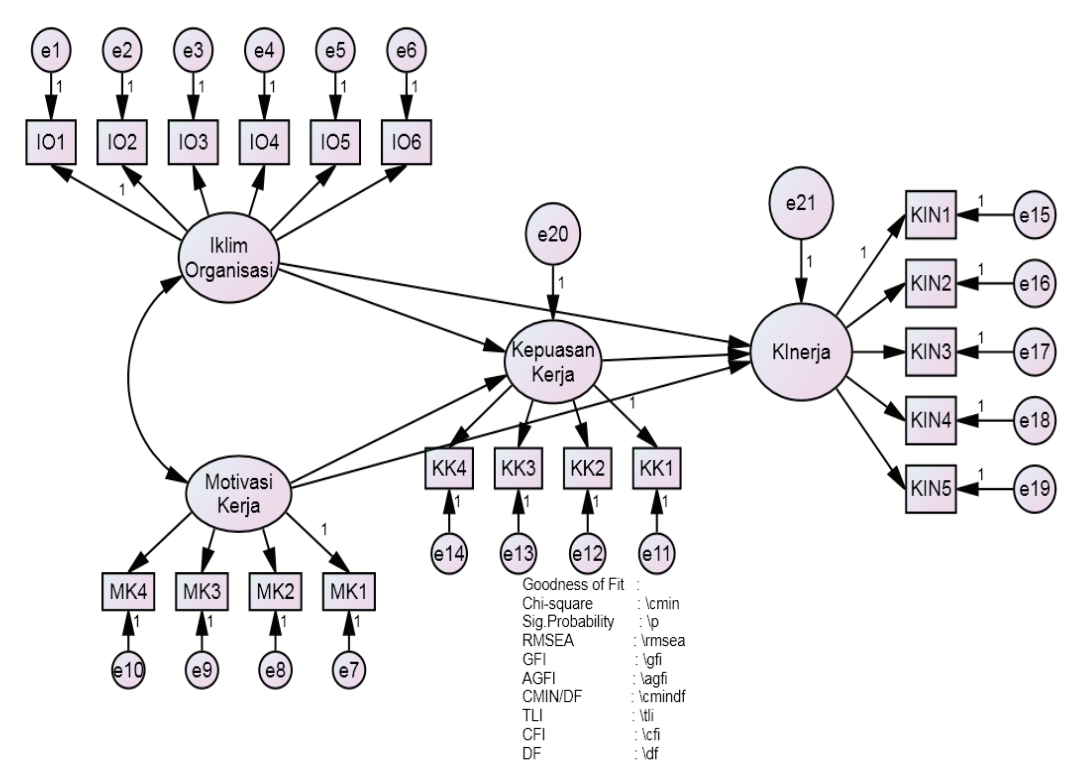

\section{Perumusan Hipotesis}

Hipotesis merupakan jawaban sementara terhadap rumusan masalah penelitian dan juga dapat diartikan sebagai tahapan selektif yang menghasilkan penekanan terhadap hal-hal yang menjadi pengecualian atau hal-hal yang merupakan konsekuensi dari suatu fenomena sosial tertentu. Dengan demikian, hipotesis dari penelitian ini adalah sebagai berikut :

H1 : Notivasi berpengaruh terhadap Kinerja Guru.

H2 : Iklim organisasi berpengaruh terhadap Kinerja Guru.

H3 : Kepuasan kerja sebagai mediator pengaruh antara motivasi terhadap Kinerja Guru.

H4 : Kepuasan kerja sebagai mediator pengaruh antara iklim organisasi terhadap Kinerja Guru.

H5 : Kepuasan kerja berpengaruh terhadap Kinerja Guru. 


\section{Metode Penelitian}

\section{Rancangan Penelitian}

Bila ditinjau dari segi tujuan penelitian, maka penelitian ini termasuk dalam kategori penelitian dasar yang bertujuan untuk mengembangkan teori, dimana penelitian ini digunakan hanya untuk melakukan penelitian dilingkungan akademik (Indriantoro \& Supono, 2002). Penelitian ini disusun untuk menjadi suatu karya ilmiah yang bertujuan untuk pengembangan ilmu pengetahuan. Penelitian ini dirancang dalam bentuk kausal komparatif karena bertujuan untuk mengetahui pengaruh antara variabel yang satu terhadap variabel yang lain. Penelitian kausal komparatif (Causal-Comparative Research) merupakan tipe penelitian dangan karateristik masalah berupa hubungan sebab-akibat antara variabel iklim organisasi dan motivasi kerja terhadap kinerja yang dimediasi oleh kepuasan kerja.

\section{Objek Penelitian}

Populasi dalam penelitian ini adalah para guru di Tembilahan. Ukuran sampel yang dijadikan dasar pengambilan sampel adalah menurut Hair, Jr., dkk maupun Tabachnick dan Fidell dalam Lerbin (2007) mengemukakan bahwa rasio antara jumlah unsur sampel dan jumlah variabel dalam suatu penelitian minimal lima kali jumlah variabel, dan lebih disarankan sepuluh kali dari jumlah variabelnya. Mereka mengemukakan lebih lanjut bahwa beberapa peneliti bahkan mengusulkan minimal 20 subjek untuk tiap variabel independennya.

Jumlah atau ukuran sampel yang ideal dalam model SEM adalah sebesar lima kali total jumlah indikator dari variabel-variabel yang diukur di dalam penelitian. Kuesioner pada penelitian ini menggunakan 4 variabel dengan pertanyaan kuesioner untuk masing-masing variabel (6 pertanyaan untuk iklim organisasi, 4 pertanyaan untiuk motivasi kerja, 4 pertanyaan untuk kepuasan kerja dan 5 pertanyaan untuk kinerja).

Karena total jumlah pertanyaan kuesioner adalah 19, maka ukuran sampel yang ideal untuk penelitian ini minimal sebesar 19 x $5=114$. Dalam penelitian ini, peneliti mendistribusikan 130 set kuesioner dengan tingkat estimasi respon yang diharapkan sebesar 120 respon. Peneliti bersama dengan beberapa distributor kuesioner yang telah dilatih menargetkan untuk menyebarkan kuesioner ke- pada populasi yang diakses dan mengumpulkan kembali semua kuesioner yang telah diisi dalam waktu 10 hari kerja.

Setiap responden diberikan satu set kuesioner, dan diminta untuk mengembalikan kuesioner yang telah di isi dengan memasukkan ke dalam sebuah kotak yang telah disediakan. Jumlah respon yang diterima berjumlah 114 .

Jadi, sampel yang akan digunakan dalam penelitian ini adalah sebanyak 114 responden.

\section{Definisi Operasional Variable}

Menurut Sugiyono (2008), pengertian variabel penelitian adalah segala sesuatu yang berbentuk apa saja yang ditetapkan oleh peneliti untuk dipelajari, sehingga diperoleh informasi tentang hal tersebut, kemudian ditarik kesimpulannya. Dalam penelitian ini penulis menggunakan dua variabel yaitu variabel independen/variabel bebas yang terdiri dari iklim organisasi, motivasi, sedangkan variabel dependen/variabel terikatnya adalah kepuasan kerja dan kinerja.

4. Iklim Organisasi

Dalam penelitian ini kuesioner iklim organisasi yang dikembangkan dan telah digunakan Stringer dikelompokan kedalam 6 (enam) dimensi yaitu Struktur, Standar, Tangggung Jawab, Pengakuan, Dukungan dan Komitmen.

\subsubsection{Motivasi Kerja}

Dalam penelitian ini variabel motivasi diukur dari indikatorindikator yang digunakan dalam penelitian Anderson dan Oliver (1987), Cravens et al. (1993), dan Low et al. (2001), serta Grant et al. (2001), yaitu: (1) perasaan berprestasi, (2) kepuasan personal, (3) kontribusi terhadap perkembangan dan pertumbuhan personal, dan (4) penghargaan terhadap diri sendiri.

\subsubsection{Kepuasan Kerja}

Variabel kepuasan kerja yang diukur yang digunakan dalam penelitian David J. Mellor al. (2003), Job satisfaction was measured using a five-point Likert scale to assess participants agreement with four statements relating to extrinsic factors (e.g. job security, physical conditions), and four statements relating to intrinsic factors (e.g. the recognition received for work done, the freedom given to do one's best at the job). Kepuasan kerja yang diukur menggunakan skala likert dengan 4 (empat) pertanyaan ber- 
hubungan dengan faktor yang disebabkan oleh keadaan luar (misalnya; jaminan sekuritas pekerjaan, kondisi fisik), dan pernyataan berhubungan dengan faktor hakiki dari dalam (misalnya. pengenalan yang didapat untuk mengerjakan selesai, kebebasan yang diberikan untuk lakukan sesuatu terbaik pada pekerjaan).

\subsubsection{Kinerja}

Kinerja menurut Mathis dan Jackson yang dikutip oleh Akhmad Subekhi dan Mohammad Jauhar (2012) menyatakan bahwa kinerja pada dasarnya adalah apa yang dilakukan atau tidak dilakukan oleh karyawan. Kinerja karyawan yang umum untuk kebanyakan pekerjaan meliputi elemen sebagai berikut:
1. Kuantitas dari hasil
2. Kualitas dari hasil
3. Kecepatan waktu dari hasil
4. Kehadiran
5. Kemampuan bekerjasama

5. Teknik Pengumpulan Data

Sumber data yang digunakan dalam penelitian adalah data primer, yaitu data yang di kumpulkan sendiri oleh peneliti dari objek penelitian. Pengumpulan data primer dilakukan dengan cara metode survei dengan menyebar kuesioner kepada responden. Kuesioner di bagikan kepada responden Guru di Tembilahan.

3.5 Metode Analisis Data

3.5.1 Metode Analisis Deskriptif

Analisa data yang digunakan untuk mengetahui kuantitas dan persentase dari karakteristik demografi responden, dalam penelitian ini adalah statistic descriptive. Demografi responden dalam penelitian ini ditinjau dari usia, jenis kelamin, status, pendidikan responden .

\subsubsection{Uji Kualitas Data}

\subsubsection{Uji Validitas}

Valid berarti instrumen yang digunakan dapat mengukur apa yang hendak diukur. Validitas yang digunakan dalam penelitian merupakan pengujian validitas isi yaitu pengujian yang dilakukan jika telah memperoleh kisikisi tersebut dapat berupa indikator sebagai tolok ukur.
Biasanya digunakan dengan menghitung korelasi antara setiap skor butir instrumen dengan skor total. Dalam melakukan penguraian validitas, digunakan alat bantu program komputer SPSS 20.0, dan jika suatu alat ukur mempunyai korelasi yang signifikan antara skor item terhadap skor totalnya maka dikatakan alat ukur tersebut adalah valid. Jika diperoleh data yang tidak valid, maka data tersebut akan dikeluarkan dan kemudian dilakukan pengujian ulang dengan metode yang sama.

Uji validitas digunakan untuk mengetahui kelayakan atas pertanyaan-pertanyaan yang diberikan. Pertanyaan dinyatakan valid jika pertanyaan pada kuesioner mampu mengungkapkan sesuatu yang akan diukur oleh kuesioner tersebut (Ghozali, 2003). Uji validitas diuji dengan menggunakan confirmatory factor analysis. Signifikansi nilai muatan faktor (factor loading) yang digunakan dalam penelitian ini adalah > 0,50 (Hair et al., 1998). Nilai muatan faktor yang lebih besar atau sama dengan 0,50 adalah valid.

\subsubsection{Uji Reliabilitas}

Sedangkan uji reliabilitas dimaksudkan untuk mengukur tingkat konsistensi instrumen penelitian. Dalam penelitian ini diuji melalui Analisis Faktor Konfirmatori, dan jika nilai Cronbach's alpha lebih besar atau sama dengan 0,70 berarti instrumen tersebut reliabel (Ghozali, 2004:21). Namun demikian, alat ukur ini dapat menjadi bias dalam beberapa kondisi tertentu (Ferdinand, 2000:171) sehingga nilai di bawah 0,70 pun bisa diijinkan, terutama untuk penelitian eksploratori (Hair et al.,1998:612). Menurut Sekaran (1992:287) jika nilai Cronbach's alpha lebih kecil dari 0,60 dikategorikan poor; dalam rentang $0,70(0,60$ sampai 0,80 ) dikategorikan dapat diterima; dan di atas 0,80 dikategorikan baik. Menurut Muhidin dan Abdurahman (2007) untuk menafsirkan hasil uji reliabilitas, kriteria yang digunakan adalah jika nilai hitung alpha lebih besar $(>)$ dari nilai tabel $r$ maka angket dinyatakan reliabel, atau jika nilai hitung alpha lebih kecil $(<)$ dari nilai tabel $r$ maka angket dinyatakan tidak reliabel. Nilai tabel $r$ dapat 
dilihat pada $\mathrm{a}=5 \%$ dan $\mathrm{db}=\mathrm{n}-2$.

Dalam penelitian ini digunakan analisis kuantitatif. Persepsi responden merupakan data kualitatif yang akan diukur dengan suatu skala Likert sehingga hasilnya berbentuk angka. Selanjutnya angka atau skor tersebut diolah dengan metode statistik. Pengukuran metode ini adalah untuk mempermudah proses analisis data.

Dari berbagai macam alat analisis, peneliti menentukan beberapa alat analisis yang sesuai dengan kebutuhan guna pembuktian hubungan hipotesis penelitian. Alat analisis yang digunakan dalam penelitian ini ada dua jenis, yaitu untuk menguji data dan untuk menguji model sesuai dengan analisis yang pernah dilakukan oleh Andini (2006) sebagai berikut:

1. Uji data

a. Uji Validitas dan Reliabilitas

b. Uji Normalitas

2. Uji model

a. Analisis Model Faktor Konfirmatori

b. Analisis Keseuasian Model (Goodness of fit)

c. Analisis Uji pengaruh (regresion weight)

Structural Equation Modelling (SEM) dengan Program AMOS 20.0 merupakan kombinasi dari analisis faktor dan analisis regresi. Teknik SEM memungkinkan seorang peneliti menguji beberapa variabel dependen sekaligus, dengan beberapa variabel independen.

Analisis SEM merupakan sekumpulan teknik statistik yang dapat digunakan untuk menganalisis permasalahan penelitian yang memiliki rangkaian hubungan yang relatif "rumit" dengan pengujian statistik secara simultan (Ferdinand, 2002) Kelebihan analisis SEM adalah dapat menganalisa multivariat secara bersamaan. Sedangkan tujuan pengunaan teknik multivariat adalah untuk memperluas kemampuan menjelaskan penelitian dan mencapai efisiensi statistik.

Sedangkan penggunaan program AMOS versi.20 untuk menganalisis masalah yang sifatnya struktural, dan digunakan untuk menganalisis dan menguji model hipotesis. Program AMOS versi.20 dapat mengestimasi koefisien yang tidak dik- etahui dari persamaan linier struktural; mengakomodasi model yang meliputi variabel laten; mengakomodasi pengukuran error baik dependen maupun independen; mengakomodasi permasalahan sebab akibat, simultan dan saling ketergantungan.

Umumnya terdapat beberapa jenis derajat kesesuaian (fit index) yang digunakan untuk mengukur derajat kesesuaian antara model yang dihipotesiskan dan data yang disajikan. Beberapa indeks kesesuaian dan nilai batas (cut-off value) yang dapat digunakan untuk menguji apakah suatu model dapat diterima atau ditolak (Ferdinand, 2002 dalam Andini, 2006) adalah sebagai berikut :

\section{1) $\chi^{2}$ - Uji Beda (Chi-Square)}

Merupakan alat uji paling fundamental untuk mengukur kesesuaian secara keseluruhan (overall fit). Chisquare bersifat sangat sensitive terhadap besarnya sampel yang digunakan, dimana penggunaan chi-square hanya sesuai bila ukuran sample antara 100 sampai 200 sampel. Model yang diuji dipandang baik atau memuaskan bila nilai chi square-nya rendah karena dalam uji beda chi square, $\chi 2=0$ berarti benar-benar tidak ada perbedaan. Semakin kecil nilai $\chi 2$ semakin baik model itu dan diterima berdasarkan probabilitas dengan cutoff value sebesar p > 0,05 atau p > 0,10 (Hulland et al., 1996 dalam Andini,2006)

2) Significance Probabilitas (Probability)

Nilai probability yang dapat diterima adalah $\mathrm{P}>0,05$.

3) RMSEA (The Root Mean Square Error of Approximation)

Merupakan sebuah indeks yang dapat digunakan untuk mengkompensasi chi-square statistic dalam sampel yang besar (Baumgarther \& Homburg, 1996) Nilai RMSEA menunjukkan nilai goodness-of-fit yang dapat diharapkan bila model diestimasi dalam populasi (Hair, et.al, 1995). Nilai RMSEA yang lebih kecil atau sama dengan 0.08 merupakan indeks untuk dapat diterimanya model yang menunjukkan sebuah close fit dari model tersebut berdasarkan degrees of freedom (Browne dan Cudeck, 1993 dalam Andini 2006).

4) GFI (Goodness of Fit Index)

Indeks kesesuaian ini akan menghitung proporsi ter- 
timbang dari varians dalam kovarians sampel yang dijelaskan oleh matriks kovarians populasi yang diestimasikan. GFI adalah sebuah ukuran non-statistikal yang mempunyai rentang antara 0 (poor fit) s.d 1.0 (perfect fit). Nilai yang tinggi dalam indeks ini menunjukkan sebuah "better fit".

5) AGFI (Adjusted Goodness of Fit Index)

Fit index ini dapat diadjust terhadap degrees of freedom yang tersedia untuk menguji diterima tidaknya model. Tingkat penerimaan yang direkomendasikan adalah bila AGFI mempunyai nilai sama dengan atau lebih besar dari 0,90 (Hair et al., 1996; Hulland et al., 1996 dalam Andini,2006) nilai sebesar 0,95 dapat diinterpretasikan sebagai tingkatan yang baik/ good overall model fit (baik), sedangkan besaran nilai antara 0,90 - 0,95 menunjukkan tingkatan cukup adequate fit (Hulland et al., 1996 dalam Andini,2006)

6) Relative Chi-Square (CMIN/DF)

Dalam hal ini CMIN/DF tidak lain adalah statistik chisquare, $\chi 2$ dibagi degree of freedom (DF), sehingga disebut $\chi^{2}$ - relatif. Nilai $\chi 2$ relatif kurang dari 2,0 atau bahkan kadang kurang dari 3,0 adalah indikasi dari acceptable fit antara model dan data (Arbuckle, 1997 dalam Andini,2006).

7) TLI - Tucker Lewis Index

TLI adalah sebuah alternative incremental fit index yang membandingkan sebuah model yang diuji terhadap sebuah baseline model. Nilai yang direkomendasikan sebagai acuan untuk diterimanya sebuah model adalah > 0,95 (Hair et al., 1995), dan nilai yang sangat mendekati 1 menunjukkan a very good fit (Arbuckle, 1997 dalam Andini, 2006).

8) CFI - Comparative Fit Index

Nilai index ini antara 0-1, dimana semakin mendekat 1 mengindikasikan tingkat fit yang paling tinggi. Nilai yang direkomendasikan adalah CFI >0,95. Keunggulan indeks ini adalah besarannya tidak dipengaruhi ukuran sample karena sangat baik untuk mengukur tingkat penerimaan sebuah model (Hulland et al., 1996; Tanaka, 1993 dalam Andini,2006).

Indeks Pengujian Kelayakan Model dan Cut-off Values adalah sebagai berikut :

1. $\chi 2$ - chi square Chi-square hit $<$ Chi-square tabel

2. Significancy probability $\geq 0.05$

3. RMSEA $\leq 0.08$

4.GFI $\geq 0.90$

5.AGFI $\geq 0.90$

6. CMIN $/ \mathrm{DF} \leq 2.00$

7.TLI $\geq 0.95$

8.CFI $\geq 0.95$

Sumber : Ferdinand, 2005 dalam Andini,2006

Variabel utama dalam penelitian ini adalah iklim organisasi, motivasi kerja, kepuasan kerja, kinerja.

3.5.3 Uji Hipotesis

Menurut Sugiyono (2008), hiposesis merupakan jawaban sementara terhadap rumusan masalah penelitian, oleh karena itu rumusan masalah penelitian biasanya disusun dalam bentuk kalimat pertanyaan. Dikatakan sementara, karena jawaban yang diberikan baru berdasarkan pada teori yang relevan, belum didasarkan pada fakta-fakta empiris yang diperoleh melalui pengumpulan data.

Adapun hipotesis yang akan diuji dan di analisis dalam penelitian ini adalah sebagai berikut:

H1 : Iklim Organisasi berpengaruh terhadap Kinerja Guru di Tembilahan.

H2 : Motivasi Kerja berpengaruh terhadap Kinerja Guru di Tembilahan.

H3 : Kepuasan Kerja memediasi pengaruh pengaruh Iklim Organisasi terhadap Kinerja Guru di Tembilahan.

H4 : Kepuasan Kerja memediasi pengaruh pengaruh Motivasi Kerja berpengaruh langsung terhadap Kinerja Guru di Tembilahan.

H5 : Kepuasan Kerja berpengaruh terhadap Kinerja Guru di Tembilahan.

3.5.4 Evaluasi terhadap Metode Penelitian a. Kekuatan (Strengths)

1. Desain penelitian ini sangat kuat karena penelitian ini menggunakan Model Persamaan Struktur (Structural 
Equation Modeling - SEM) yang sifatnya tidak bias (un biased) untuk menguji hipotesis.

2. Pertanyaan-pertanyaan dalam kuesioner yang digunakan dalam penelitian ini memiliki tingkat reliabitas dan validitas yang baik.

3. Penelitian ini menggiunakan metode penelitian kuantitatif untuk menginvestigasi populasi yang besar.

4. Populasi sasaran (target population) dan populasi akses (accessible population) sangat homogen dan kriterian sampel ditentukan dengan kriteria yang jelas.

5. Peneliti melakukan analisis faktor secara parsial terhadap maisng-masing indikator untuk memastikan bahwa indikator tersebut secara signifikan mendefinisikan laten variabel yang dibentuk dengan cara mengukur nilai lamda $(\lambda)$, nilia koefisien C.R serta nilai probalilitas.

\section{DAFTAR PUSTAKA}

Andini, Rita, 2006, Analisis Pengaruh Kepuasan Gaji, Kepuasan Kerja, Komitmen Organisasional terhadap Turnover Intention: Studi Kasus Pada Rumah Sakit Roemani Muhammadiyah Semarang, Magister Management,Universitas Diponegoro Semarang.

Arsyad Supardi dan M. Anwar. (2004). Manajemen dan Organisasi. Pustaka Ilmu. Jakarta.

David J. Mellor al. (2003). How can managers reduce employee intention to quit?. Journal of Managerial Psychology Vol. 19 No. 2, pp. 170-187

Ferdinand, Agusty, 2006, Metode Penelitian Manajemen, Edisi Kedua, Badan Penerbit Universitas Diponegoro., 2000, Structural Equation Modeling Dalam Penelitian Manajemen, Semarang: BP Universitas Diponegoro

Ghozali, I. (2003) Analisis Multivariate dengan Program SPSS. Semarang: Badan Penerbitan Universitas Diponegoro.

Ghozali, I. (2004). Aplikasi Analisis Multivariate dengan Program SPSS.
Semarang: Badan Penerbit Universitas Diponegoro.

Grant, K., D. W. Cravens, G. S. Low dan W. C. Moncrief, 2001, The Role of Satisfaction With Territory Desig on the Motivation, Attitudes, and Work Ourcomes of Salespeople, Journal of the Academy of Marketing Science, 29(2), 165-178.

Hair, J. F. Jr, R.E., Anderson, R. L., Tatham, \& W.C. Black. (1998). Multivariate Data Analysis. New Jersey: Prentice Hall, Inc.

Heidjrachman, R. dan Husnan, S. 2002. Manajemen Personalia. Edisi Keempat. Yogyakarta: BPFE.

Hilda., dkk., (2004). Analisis Faktor-faktor yang Berpengaruh Terhadap Keinginan Karyawan Untuk Pindah. Jurnal Studi Manajemen \& Organisasi. Vol. 1 No. 2, halaman. 16.

Indriantoro, Nur., dan Bambang Supomo, 2002, Metodologi Penelitian Bisnis, Badan Penerbit Universitas Gajahmada, Yogyakarta

Irham Fahmi (2010). Manajemen Kinerja. Bandung: Alfabeta.

Kotler, Philip. (2003). Marketing Management, Eleventh Edition. New Jersey: Prentice-Hall International, Inc.

Lerbin R. Aritonang R. (2007). Riset Pemasaran. Bogor : Ghalia Indonesia.

Liew Chai Hong and Sharan Kaur. (2008). A Relationship between Organizational Climate, Employee Personality and Intention to Leave. International Review of Business Research Papers Vol. 4 No.3. Pp.1-10.

Mahsun ,M., (2006), Pengukuran Kinerja Sektor Publik, BPFE Yogyakarta,

Mohammad Jauhar (2012). Pengantar MSDM. Jakarta: Prestasi Pustakaraya.

Muhidin, Sambas Ali., Abdurahman, Maman. (2007). Anallisis Korelasi, Regresi, dan Jalur dalam Penelitian. Bandung : CV. Pustaka Setia.

Mulyadi. (2007). Sistem Perencanaan pesiar Pengendalian Manajemen. Salemba Empat,

Natassia Ayudiarini,_________ Pengaruh Iklim Organisasi dan Pengembangan Karir, Universitas Gunadarma.

Notoatmojo, Soekidjo, 2003, Pengembangan Sumber Daya Manusia, Rineka Cipta, Jakarta.

Prawirosentono.S. 1999. Kebijakan Kinerja Karyawan, Edisi Pertama, 
BPFE, Yogyakarta.

Rismawati (2008). Pengaruh Motivasi Kerja Dan Budaya Organisasi Terhadap Kinerja Dosen Politeknik Negeri Medan. Universitas Sumatera Utara. Medan

Rivai, V.2005. Manajemen Sumber Daya Manusia Untuk Perusahaan Dari Teori Ke Praktek .Cetakan Pertama. Jakarta: PT. Raja Grafindo Persada.

Robert L. Mathis - John H. Jackson (2006). Manajemen Sumber Daya Manusia, Edisi 10. Jakarta: Salemba Empat.

Ronald Listio (2010). Pengaruh Kompetensi Dan Motivasi Kerja Ter hadap Kinerja Karyawan PT. Allianz Life Indonesia Wilayah Jawa Barat. Universitas Komputer Indonesia. Bandung

Sugiyono, (2008). Metode Penelitian Bisnis, Edisi ke-12, Bandung: CV. Alfabeta

Undang-undang nomor 20 tahun 2003 Tentang Sistim Pendidikan Nasional

Wahyuningrum (2008). Hubungan Kemampuan, Kepuasan dan Disiplin Kerja dengan Kinerja Pegawai di Kecamatan Tanggungharjo Kabu paten Grobongan. Semarang: Universitas Diponegero Semarang.

Whitmore, J., 1997, Pelatihan bagi Performance, Seni Mengarahkan Untuk Mendongkrak Kinerja, (alih bahasa Dwi), Gramedia Pustaka Utama. Jakarta.

Windra Mai Haryanto (2011). Analisis Pengaruh Motivasi, Komitmen Organisasi, dan Kepuasan Kerja terhadap Kinerja Kary awan (Studi Kasus PT. Bank DKI). Institut Pertanian Bogor.

Woro Mustika Ning Tyas, 2014 pengaruh pembinaan disiplin kerja terhadap iklim kerja pegawai di pt krakatau industrial estate cilego, universitas pendidikan indonesia.

\section{PEDOMAN PENULISAN}

1. Naskah ditulis dalam bentuk essay, berisi gagasan atau analisis konseptual yang orisinil, hasil penelitian, atau book review, dalam bidang ilmu-ilmu keislaman, yang mencakup: Ilmu Ekonomi Syariah, serta pemikiran ke-Islaman.

2. Panjang naskah adalah antara 10-20 halaman kertas kwarto/A.4, diketik dengan 1,5 spasi atau yang setara, dengan margin: kiri dan atas 4 $\mathrm{cm}$, margin kanan dan bawah $3 \mathrm{~cm}$.

3. Naskah diketik dengan menggunakan huruf/font Times New Roman untuk Latin, ukuran 12, dan Tradisional Arabic ukuran 18 untuk tulisan berbahasa Arab, atau ukuran 16 untuk teks Arab kutipan, seperti kutipan pendapat, dan kutipan ayat dan hadis, sedangkan dalam catatan kaki huruf Latin dengan font 10 dan Bahasa Arab dengan font 15.

4. Komponen naskah yang harus ditulis secara jelas secara berurutan adalah a) Judul tulisan, b) Nama penulis, tanpa gelar, dan di sebelah kanan atas nama penulis diberi footnote dengan tanda (*), di dalamnya dijelaskan tentang pendidikan terakhir penulis, tempat tugas, dan bidang studi yang digeluti penulis, serta informasi yang relevan lainnya, c) Abstrak berbahasa asing (Arab-Inggris) atau berbahasa Indonesia (maksimal 100 kata), d) Kata kunci atau key words dari tulisan, e) pendahuluan atau prolog, f) isi (deskripsi dan analisis), dapat dibagi kepada beberapa sub bahasan, g) Kesimpulan, dan h) Daftar rujukan. Jika tulisan yang dikirim adalah hasil penelitian (riset), maka harus ditambah dengan memuat; latar belakang, tinjauan pustaka, tujuan, metode penelitian, dan hasil penelitian.

5. Kutipan harus dijelaskan sumbernya dalam bentuk foot note, yang memuat; nama pengarang (sesuai dengan nama di daftar rujukan), (misalnya; Muhammad Husain al-Zahabi. Al-Tafsir wa Al-Mufassirun. Jilid IV. (T. Tp: T.th), hlm. 301.)

6. Tulisan harus dilengkapi dengan Daftar Rujukan, yaitu sumber tertulis yang benar-benar digunakan dalam penulisan naskah. Cara penulisan daftar rujukan adalah; nama penulis secara lengkap, bagian akhir dari nama penulis ditulis paling awal, dan antara nama akhir dengan nama selanjutnya diberi batas dengan koma (,); lalu judul buku ditulis italic/ miring, kota tempat terbit, nama penerbit, tahun terbit, cetakan ke. Baris kedua dari buku sumber harus dimasukkan ke kanan, sejauh 7 spasi. Misalnya: 